\title{
Reliable determination of Prorocentrum micans Ehrenb. (Prorocentrales, Dinophyceae) based on newly collected material from the type locality
}

\section{Urban Tillmann, Mona Hoppenrath \& Marc Gottschling}

To cite this article: Urban Tillmann, Mona Hoppenrath \& Marc Gottschling (2019) Reliable determination of Prorocentrum micans Ehrenb. (Prorocentrales, Dinophyceae) based on newly collected material from the type locality, European Journal of Phycology, 54:3, 417-431, DOI: 10.1080/09670262.2019.1579925

To link to this article: https://doi.org/10.1080/09670262.2019.1579925

View supplementary material $₫$

曲 Published online: 13 May 2019.

Submit your article to this journal

Џll Article views: 52

Q View related articles $\sqsubset$

View Crossmark data $₫$ 


\title{
Reliable determination of Prorocentrum micans Ehrenb. (Prorocentrales, Dinophyceae) based on newly collected material from the type locality
}

\author{
Urban Tillmann $\mathbb{1}^{\mathrm{a}}{ }^{\mathrm{a}}$, Mona Hoppenrath ${ }^{\mathrm{b}}$ and Marc Gottschling $\mathbb{1}^{\mathrm{c}}$ \\ ${ }^{a}$ Alfred Wegener Institut, Helmholz-Zentrum für Polar- und Meeresforschung, Am Handelshafen 12, D - 27570 Bremerhaven, \\ Germany; 'benckenberg am Meer, German Centre for Marine Biodiversity Research (DZMB), Südstrand 44, D - 26382 \\ Wilhelmshaven, Germany; ${ }^{\mathrm{c}}$ Department Biologie, Systematische Botanik und Mykologie, GeoBio-Center, Ludwig-Maximilians- \\ Universität München, Menzinger Str. 67, D - 80638 München, Germany
}

ABSTRACT

The Prorocentrales are a unique group of dinophytes based on several apomorphic traits, but species delimitation is challenging within the group. The type species of Prorocentrum, namely P. micans, cannot be determined unambiguously, as important characters are not preserved in the original material collected in the first half of the 19th century. Water samples were taken at the type locality of P. micans in the Baltic Sea off Kiel (Germany) and strains with a morphology consistent with the protologue were established. An in-depth morphological analysis was performed, illustrating minute traits such as the periflagellar platelets and three different types of thecal pores. rRNA sequence data allowed for molecular characterization of the species. The newly collected material of $P$. micans was used for epitypification with the result that the type species of Prorocentrum can now be determined unambiguously.

ARTICLE HISTORY Received 9 October 2018; Revised 21 December 2018; Accepted 4 January 2019

KEYWORDS Epitypification; DNA sequence barcode; morphology; taxonomy

\section{Introduction}

The Prorocentrales are a unique group of dinophytes, in which cingulum and sulcus are absent and the flagella are inserted apically (desmokont flagellation: Dodge, 1975; Fensome et al., 1993; Murray et al., 2009; Hoppenrath et al., 2013). The theca consists of two large, lateral thecal plates, separated by a sagittal suture, and a cluster of small, periflagellar platelets surrounding two large pores, one of which is the flagellar pore (prorocentroid tabulation: Fensome et al., 1993; Hoppenrath et al., 2013). The platelets of the periflagellar area, and their associated structures, are diverse and probably species-specific (Hoppenrath et al., 2013). Despite the distinct morphology, the Prorocentrales lineage has rarely been shown to be monophyletic in molecular phylogenetics, if a broad dinophyte taxon sample is used (Murray et al., 2009; Orr et al., 2012; Gu et al., 2013; Bachvaroff et al., 2014).

Prorocentrum micans Ehrenberg is one of the best known and most widely distributed dinophycean species (Dodge, 1975). It is marine and mainly neritic and has been globally recorded along the coasts of the northern Pacific and of the Atlantic in the northern and southern hemisphere, the Baltic Sea and the Mediterranean Sea (Ehrenberg, 1836; Bergh, 1881; Stein, 1883; Paulsen, 1907; Lohmann, 1908; Lebour, 1925; Braarud \& Rossavik, 1951; Biecheler, 1952; Silva, 1959; Abé, 1967; Dodge, 1982; Paulmier,
1992; Cohen-Fernandez et al., 2006; Hoppenrath et al., 2009; Omura et al., 2012; Han et al., 2016). Prorocentrum micans is also found in the Arctic (Okolodkov, 1998; Caroppo et al., 2017) but, to the best of our knowledge, there are no records from the Antarctic Ocean. The species is well known for usually non-toxic blooms in many coastal areas of the world (Braarud \& Rossavik, 1951; Cassie, 1981; Pitcher \& Calder, 2000), and maximum densities of up to 20 million cells per litre have been reported (Braarud \& Heimdal, 1970). Some P. micans blooms have been described as noxious, affecting shellfish (Shumway, 1990), but these negative effects are due more to low oxygen availability. A few early reports on P. micans producing toxins (Pinto \& Silva, 1956) are doubtful and have never been confirmed.

Ecologically, P. micans is mixotrophic (Jacobson \& Anderson, 1996; Jeong et al., 2005) and feeds myzocytotically with a peduncle (Schnepf \& Winter 1990). The cells are easy to cultivate and, thus, there are numerous studies of $P$. micans regarding growth requirements (Kain \& Fogg, 1960), clonal variability in growth rate (Brand, 1985), use of dissolved organic compounds (Mahoney \& McLaughlin, 1977), taxis and migration (Hasle, 1950; Eggersdorfer \& Häder, 1991), allelochemical interactions (Uchida, 1977; Jin et al., 2005), population genetic diversity (Shankle et al., 2004), ultrastructure (Dodge \& Bibby, 1973; Schnepf \& 
Winter, 1990; Roberts et al., 1995) and life-history (Braarud \& Rossavik, 1951; Bhaud et al., 1988).

Prorocentrum micans is the type of Prorocentrum Ehrenberg (ICZN Art. 13.4.) and of the Prorocentrales, and is amongst the first 20 scientific names ever introduced in the dinophytes. The species was described by Ehrenberg (1835), who observed it in water tow samples from the Kiel Fjord (Baltic Sea, Germany) collected by the amateur naturalist G.A. Michaelis in September 1832 (Ehrenberg, 1836). Christian G. Ehrenberg's minute water-colour drawings show cells exhibiting chloroplasts and with an outline that is asymmetrically obovate with acute antapex and a spine at the apex. The length of the cells is documented as $\sim 60 \mu \mathrm{m}$, and Ehrenberg (1835) was unsure whether the species was bioluminescent. Kusber et al. (2005) inspected the original material including a mica of P. micans (preparation No. 540164-1, BHUPM) and lectotypified the taxon based on a cell (illustrated as their figs 2-4) in a lower ring marking a number of cells. However, this material is not informative in
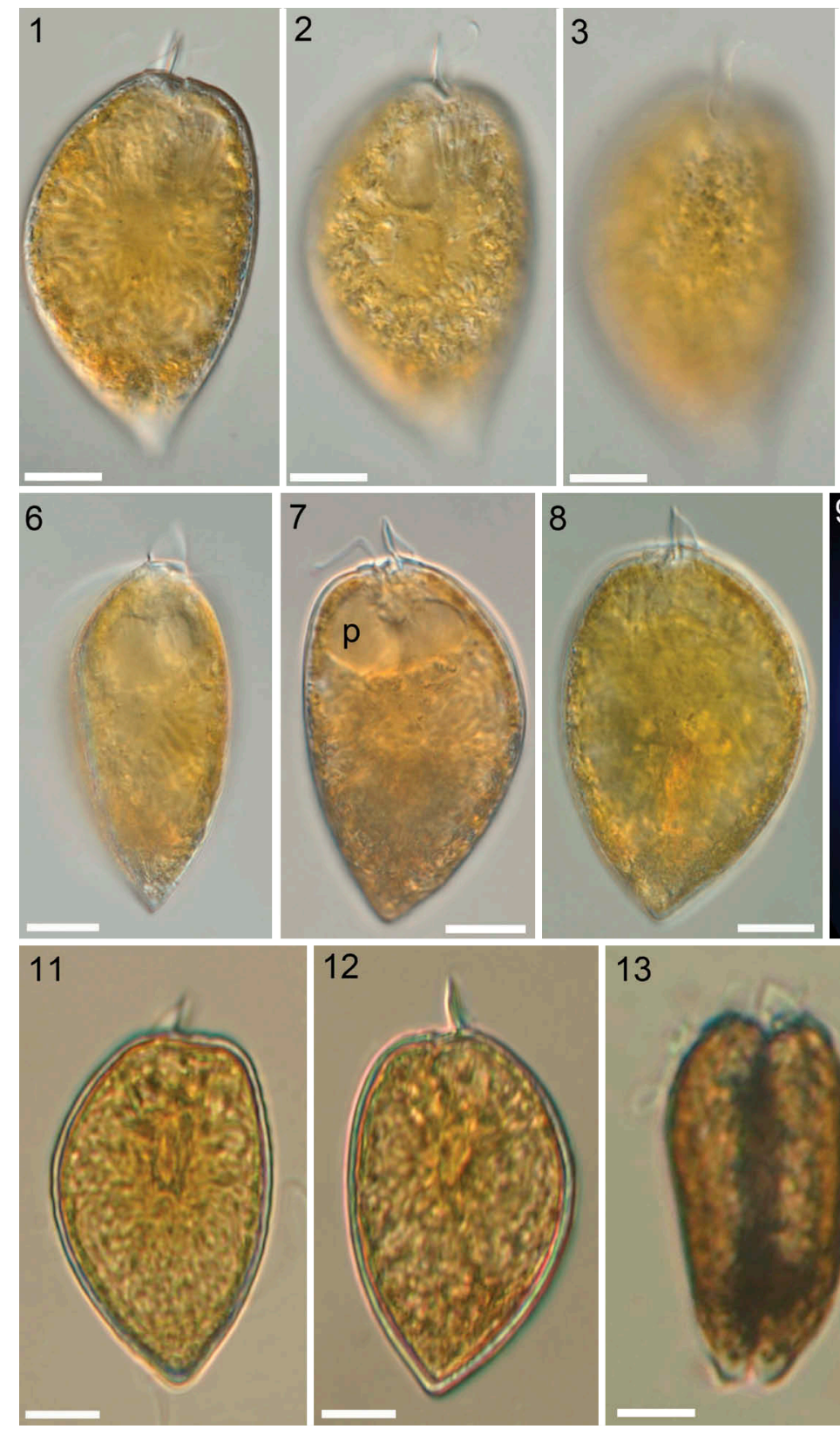
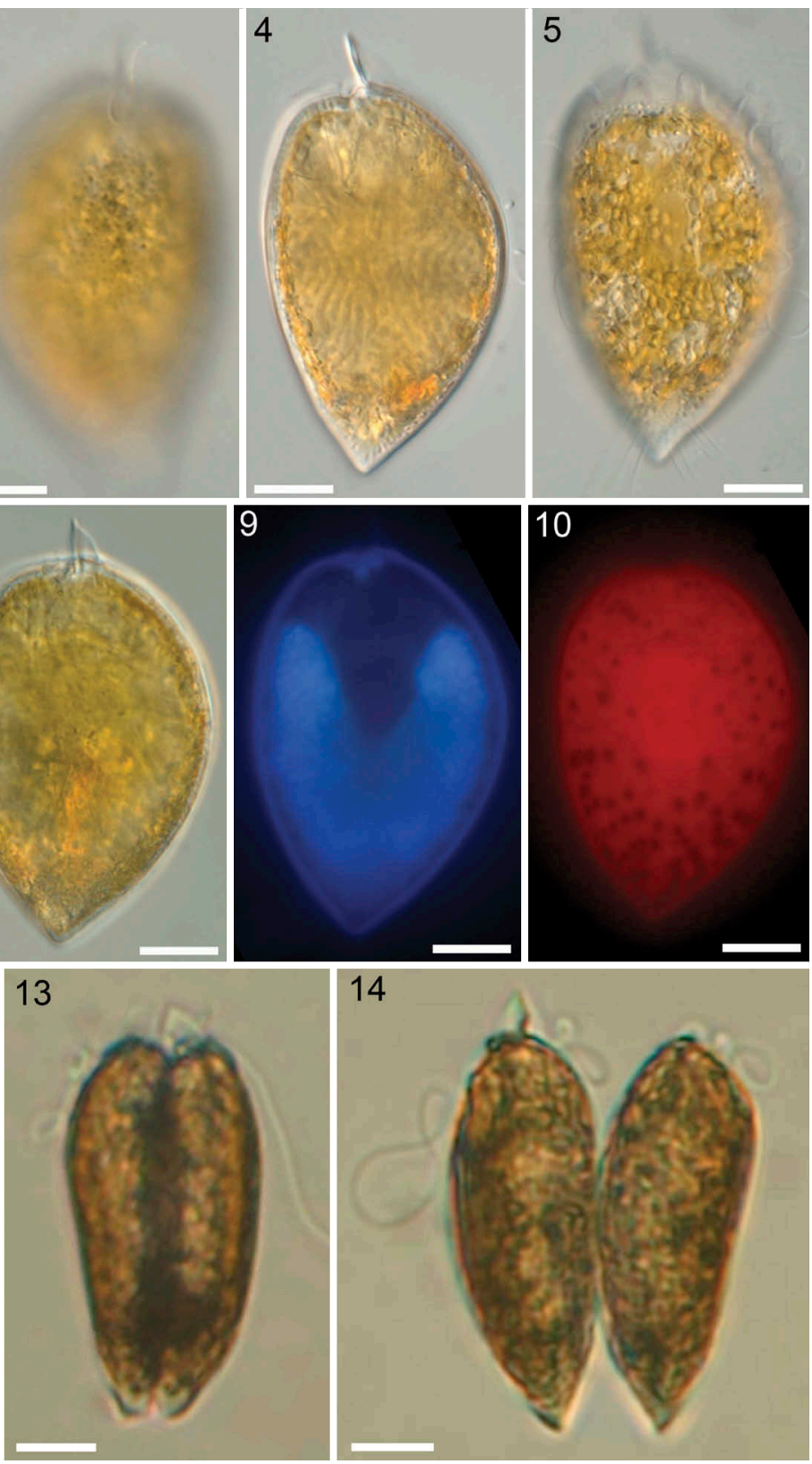

Figs 1-14. Prorocentrum micans (strain A10, LM). Figs 1-7, 13, 14. Living cells. Figs 8-10. Formalin-fixed cell. Figs $11,12$. Lugol-fixed cells. Figs 1-7. General size and shape of cells in lateral view of the right thecal plate (Figs 1-3), the left thecal plate (Figs 4, 5, 7, 8) and in ventral view (Fig. 6). Note the large apical trichocyst rods in Fig. 2, the poroid surface structure in Fig. 3, the thick chromosomes visible in Fig. 4, the radiating extruded trichocysts visible in Fig. 5, and the presumptive pusule (p) in Fig. 7. Figs 8-10. The same formalin-fixed cell stained with DAPI in brightfield (Fig. 8), with UV excitation (Fig. 9) to illustrate shape and position of the nucleus, and with blue light excitation (Fig. 10), when chlorophyll autofluorescence indicated chloroplast structure. Figs 11, 12. Right (Fig. 11) and left (Fig. 12) thecal plate of Lugol-fixed cells. Note the central, darkly stained area. Figs 13, 14. Ventral view of two stages during cell division. Scale bars $=10 \mu \mathrm{m}$. 
terms of morphological details (e.g. pore types and their distribution at the cell surface, microarchitecture of periflagellar platelets) and of DNA sequence data.

Because of limited information, the original material of $P$. micans is ambiguous and the species can therefore not be critically identified for purposes of the precise application of the name (ICN Art. 9.9). Many species of Prorocentrum can be easily confused (Dodge, 1975; Lin et al., 2006; Nagahama et al., 2011; Hoppenrath et al., 2013; Herrera-Sepúlveda et al., 2015; Gómez et al., 2017), and DNA sequence information is particularly essential in this group for reliable determination. Morphologically, P. micans has been considered to be very variable (Braarud \& Rossavik, 1951; Bursa, 1959; Dodge, 1975) and the delimitation from similar species such as Prorocentrum gracile F.Schütt, Prorocentrum triestinum J.Schiller or Prorocentrum mexicanum OsorioTafall might be unclear (Taylor, 1976; Faust et al., 1999; Hernández-Becerril et al., 2000; CohenFernandez et al., 2006). Moreover, Prorocentrum texanum var. cuspidatum Henrichs, Steidinger, P.S. Scott \& L.Campbell described in 2013 (Henrichs et al., 2013) is genetically distinct but morphologically similar to $P$. micans. The same applies to the recently described species Porocentrum koreanum M.S.Han, S.Y.Cho \& P.Wang (Han et al., 2016), which is very similar if not indistinguishable from Ehrenberg's species, despite distinct genetic differences from strains listed as $P$. micans. In light of such uncertainties, the present study follows an epitypification approach (ICN Art. 9.8; Day et al., 2010) that has turned out to be taxonomically useful for historical scientific names in dinophytes (Kretschmann et al., 2015, 2018; Tillmann et al., 2017). New material of $P$. micans was collected at the type locality in the Baltic Sea off Kiel and the present study aimed at the reliable determination of this ecologically and taxonomically important species.

\section{Materials and methods}

\section{Sampling, cell isolation, cultivation}

A surface water sample (temperature: $13.7^{\circ} \mathrm{C}$, salinity: 15) was taken at the Kiel Fjord (Baltic Sea off Germany) from a harbour pier $\left(54^{\circ} 20^{\prime} 41.0^{\prime \prime} \mathrm{N}, 10^{\circ} 09^{\prime}\right.$ $\left.21.5^{\prime \prime} \mathrm{E}\right)$ with a bucket on 20 October 2017. Single cells (exhibiting a morphology consistent with Prorocentrum) were isolated by micro-capillary into 96-well plates filled with $0.2 \mathrm{ml}$ filtered water from the sample site. Plates were incubated at $15^{\circ} \mathrm{C}$ under $50 \mu \mathrm{mol}$ photons $\mathrm{m}^{-2} \mathrm{~s}^{-1}$ on a 16:8 h light:dark photocycle in a controlled environment growth chamber (Sanyo Biomedica MIR 252; Wood Dale, Illinois, USA.

A total of 12 clonal strains of $P$. micans (Table 1) were established and cultivated in the conditions described above. Six of them were grown in natural seawater medium consisting of sterile filtered $(0.2 \mu \mathrm{m}$ VacuCap filters; Pall Life Sciences; Dreieich, Germany) and diluted North Sea water with a salinity of 15 , and the other group of six strains in a full saline (salinity 33 )

Table 1. Cell dimensions of 12 Prorocentrum micans strains grown in a salinity of either 15 or 33.

\begin{tabular}{|c|c|c|c|c|c|c|}
\hline Strain & Salinity & $\begin{array}{c}\text { Length }(\mu \mathrm{m}) \\
\text { mean } \pm \mathrm{SD} \\
\min -\max \end{array}$ & $\begin{array}{c}\text { Depth }(\mu \mathrm{m}) \\
\text { mean } \pm \mathrm{SD} \\
\min -\max \end{array}$ & $\begin{array}{c}\mathrm{L} / \mathrm{D} \text { ratio } \\
\text { mean } \pm \mathrm{SD} \\
\min -\max \end{array}$ & 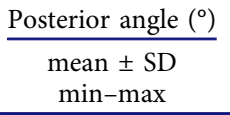 & $N$ \\
\hline A4 & 15 & $\begin{array}{l}49.6 \pm 1.6 \\
44.4-53.8\end{array}$ & $\begin{array}{c}30.5 \pm 1.4 \\
26.8-33.4\end{array}$ & $\begin{array}{l}\mathbf{1 . 6 3} \pm 0.05 \\
1.52-1.79\end{array}$ & $\begin{array}{c}80.8 \pm 5.0 \\
61.3-93.9\end{array}$ & 75 \\
\hline A 10 & 15 & $\begin{array}{c}48.8 \pm 1.6 \\
40.5-51.9\end{array}$ & $\begin{array}{c}29.6 \pm 1.4 \\
24.4-32.4\end{array}$ & $\begin{array}{l}\mathbf{1 . 6 5} \pm 0.06 \\
1.50-1.78\end{array}$ & $\begin{array}{c}\mathbf{8 2 . 1} \pm 6.0 \\
68.8-109.8\end{array}$ & 87 \\
\hline B8 & 15 & $\begin{array}{c}\mathbf{5 0 . 5} \pm 2.0 \\
43.1-55.1\end{array}$ & $\begin{array}{c}29.7 \pm 1.3 \\
26.3-32.3\end{array}$ & $\begin{array}{l}1.70 \pm 0.06 \\
1.54-1.89\end{array}$ & $\begin{array}{c}\mathbf{8 0 . 1} \pm 6.2 \\
69.9-109.3\end{array}$ & 73 \\
\hline B11 & 15 & $\begin{array}{c}\mathbf{5 0 . 6} \pm 1.8 \\
42.9-53.6\end{array}$ & $\begin{array}{c}\mathbf{3 0 . 1} \pm 1.5 \\
26.9-33.0\end{array}$ & $\begin{array}{l}\mathbf{1 . 6 8} \pm 0.06 \\
1.55-1.86\end{array}$ & $\begin{array}{c}81.8 \pm 6.3 \\
66.2-109.4\end{array}$ & 75 \\
\hline $\mathrm{C} 8$ & 15 & $\begin{array}{c}\mathbf{4 8 . 1} \pm 2.0 \\
41.8-51.3\end{array}$ & $\begin{array}{c}29.0 \pm 1.2 \\
26.2-31.7\end{array}$ & $\begin{array}{l}\mathbf{1 . 6 6} \pm 0.06 \\
1.52-1.79\end{array}$ & $\begin{array}{l}82.3 \pm 6.4 \\
66.4-99.4\end{array}$ & 74 \\
\hline D10 & 15 & $\begin{array}{c}\mathbf{4 8 . 4} \pm 1.5 \\
43.0-53.3\end{array}$ & $\begin{array}{c}29.1 \pm 1.2 \\
25.2-31.3\end{array}$ & $\begin{array}{l}1.67 \pm 0.05 \\
1.56-1.86\end{array}$ & $\begin{array}{c}\mathbf{8 3 . 6} \pm 4.7 \\
73.7-99.5\end{array}$ & 72 \\
\hline A 3 & 33 & $\begin{array}{c}\mathbf{5 3 . 6} \pm 1.6 \\
49.8-58.0\end{array}$ & $\begin{array}{c}31.2 \pm 1.2 \\
29.0-34.8\end{array}$ & $\begin{array}{c}1.72 \pm 3.8 \\
1.71-1.61\end{array}$ & $\begin{array}{l}76.7 \pm 3.8 \\
66.4-85.7\end{array}$ & 83 \\
\hline B1 & 33 & $\begin{array}{c}\mathbf{5 2 . 3} \pm 1.7 \\
49.1-55.8\end{array}$ & $\begin{array}{c}32.2 \pm 1.5 \\
29.0-35.7\end{array}$ & $\begin{array}{l}1.63 \pm 0.04 \\
1.56-1.72\end{array}$ & $\begin{array}{c}\mathbf{8 1 . 5} \pm 3.6 \\
72.3-89.3\end{array}$ & 70 \\
\hline B3 & 33 & $\begin{array}{c}\mathbf{5 2 . 3} \pm 1.5 \\
48.3-54.9\end{array}$ & $\begin{array}{c}31.1 \pm 1.1 \\
28.6-33.4\end{array}$ & $\begin{array}{l}1.68 \pm 0.04 \\
1.60-1.78\end{array}$ & $\begin{array}{l}77.2 \pm 3.4 \\
69.6-91.4\end{array}$ & 73 \\
\hline $\mathrm{C} 3$ & 33 & $\begin{array}{c}\mathbf{5 1 . 5} \pm 1.4 \\
48.2-54.7\end{array}$ & $\begin{array}{c}30.7 \pm 1.0 \\
28.3-33.7\end{array}$ & $\begin{array}{l}\mathbf{1 . 6 8} \pm 0.04 \\
1.57-1.81\end{array}$ & $\begin{array}{c}78.6 \pm 3.8 \\
71.8-91.0\end{array}$ & 86 \\
\hline D3 & 33 & $\begin{array}{c}\mathbf{5 1 . 9} \pm 1.8 \\
46.4-56.4\end{array}$ & $\begin{array}{c}\mathbf{3 2 . 1} \pm 1.6 \\
26.4-35.9\end{array}$ & $\begin{array}{l}1.62 \pm 0.05 \\
1.53-1.76\end{array}$ & $\begin{array}{c}85.3 \pm 4.7 \\
72.6-94.9\end{array}$ & 78 \\
\hline D6 & 33 & $\begin{array}{c}\mathbf{5 2 . 9} \pm 1.5 \\
50.1-58.2\end{array}$ & $\begin{array}{c}31.4 \pm 1.0 \\
28.8-34.5\end{array}$ & $\begin{array}{l}1.69 \pm 0.04 \\
1.60-1.84\end{array}$ & $\begin{array}{c}76.6 \pm 3.8 \\
65.3-88.1\end{array}$ & 82 \\
\hline
\end{tabular}

For a sketch on how morphometric size measurements were performed see Supplementary fig. S1A. Note that all strains sequenced (i.e. A10, B11, D10) are identical with respect to their rRNA sequence. 
seawater medium. Both salinity media were enriched with nutrients corresponding to $50 \%$ of $\mathrm{K}$-medium (Keller et al., 1987) slightly modified by omitting ammonium ions.

For DNA harvest, cells were collected by centrifugation (Eppendorf 5810R; Hamburg, Germany) in $50 \mathrm{ml}$ centrifugation tubes at $3220 \times \mathrm{g}$ for $10 \mathrm{~min}$. Cell pellets were transferred to $1 \mathrm{ml}$ microtubes, then again centrifuged (Eppendorf 5415, 16000×g, $5 \mathrm{~min}$ ) and stored frozen $\left(-20^{\circ} \mathrm{C}\right)$ for subsequent DNA extraction. In addition, all strains were grown and harvested as described above for lipophilic toxin analysis and stored at $-20^{\circ} \mathrm{C}$ until use. For each harvest, cell density was determined by settling Lugol-fixed samples and counting $>800$ cells under an inverted microscope.

\section{Microscopy}

Observation of living or fixed cells (formaldehyde: 1\% final concentration, or neutral Lugol-fixed: $1 \%$ final concentration) was carried out using an inverted microscope (Axiovert 200M; Zeiss; Munich, Germany) and a compound microscope (Axiovert 2; Zeiss), both equipped with epifluorescence and differential interference contrast optics. The shape and location of the nucleus was determined after staining of formalin-fixed cells with 4'-6-diamidino-2-phenylindole (DAPI, $0.1 \mu \mathrm{g} \mathrm{ml}^{-1}$ final concentration) for 10 min. Images were taken either with a digital camera (Axiocam MRc5; Zeiss), or videos were recorded using a digital camera (Gryphax Jenoptik; Jena, Germany) at full-HD resolution. Single frame micrographs were then extracted using Corel Video Studio software (Version X8, Coral; Ottawa, Canada).

Length and width of freshly fixed cells (neutral Lugol) from dense but healthy and growing strains (based on stereomicroscopic inspection of the living material) during late exponential phase were measured at microscopic magnification of $640 \times(1000 \times$ for spine length $)$ using the inverted microscope and the Axiovision software (Zeiss). A detailed sketch on how morphometric size measurements were performed is provided as supplementary material (Supplementary fig. S1).

For scanning electron microscopy (SEM), cells were collected by centrifugation (Eppendorf 5810R; $3220 \times g$ for $10 \mathrm{~min}$ ) from $15 \mathrm{ml}$ of the strain. The supernatant was removed and the cell pellet re-suspended in $60 \%$ ethanol prepared in a $2 \mathrm{ml}$ microtube with seawater (final salinity $\sim 13$ ) at $4^{\circ} \mathrm{C}$ for $1 \mathrm{~h}$ in order to strip off the outer cell membrane. Cells were further collected by centrifugation (Eppendorf 5415R; $16000 \times g$ for $5 \mathrm{~min}$ ) and re-suspended in a 60:40 mixture of deionized water and seawater (final salinity $\sim 13$ ) at $4^{\circ} \mathrm{C}$ for $30 \mathrm{~min}$. After centrifugation and removal of the diluted seawater supernatant, cells were fixed with formaldehyde ( $2 \%$ final concentration in a 60:40 mixture of deionized water and seawater) and stored at $4^{\circ} \mathrm{C}$ for $3 \mathrm{~h}$. Alternatively, cells were treated with TritonX (Sigma-Aldrich; St. Louis, Missouri, USA) at $0.5 \%$ final concentration for $3 \mathrm{~h}$.

Cells from both treatments were collected on polycarbonate filters (Millipore Merck; Darmstadt, Germany; $25 \mathrm{~mm} \varnothing, 3 \mathrm{~mm}$ pore-size) in a filter funnel, in which all subsequent washing and dehydration steps were carried out. A total of eight washing steps ( $2 \mathrm{ml}$ MilliQ-deionized water each) were followed by a dehydration series in ethanol $(30 \%, 50 \%, 70 \%, 80 \%$, 95\%, 100\%; $10 \mathrm{~min}$ each). Filters were dehydrated with hexamethyldisilazane (HMDS), first in 1:1 HMDS:EtOH, followed by twice 100\% HMDS, and then stored in a desiccator under gentle vacuum. Finally, filters were mounted on stubs, sputter coated (Emscope SC500; Ashford, UK) with gold-palladium and viewed at $10 \mathrm{kV}$ under a SEM (FEI Quanta FEG 200; Eindhoven, the Netherlands). Micrographs were presented on a black background using Photoshop 6.0 (Adobe Systems; San Jose, California, USA).

\section{Toxin analysis}

Cell pellets were suspended in $500 \mu \mathrm{l}$ methanol and subsequently transferred to a FastPrep tube containing $0.9 \mathrm{~g}$ lysing matrix D (Thermo Savant; Illkirch, France). The samples were homogenized by reciprocal shaking at maximum speed $\left(6.5 \mathrm{~m} \mathrm{~s}^{-1}\right)$ for $45 \mathrm{~s}$ in a Bio101 FastPrep instrument (Thermo Savant). After homogenization, samples were centrifuged (Eppendorf $5415 \mathrm{R}$ ) at $16100 \times g$ at $4^{\circ} \mathrm{C}$ for $15 \mathrm{~min}$. The supernatant $(400 \mu \mathrm{l})$ was transferred to a spin-filter (pore-size $0.45 \mu \mathrm{m}$; Millipore Ultrafree; Eschborn, Germany) and centrifuged for $30 \mathrm{~s}$ at $800 \times g$. The filtrate was transferred to an autosampler vial and analysed by LC-MS-MS for the presence of okadaic acid as described in Krock et al. (2008).

\section{DNA sequencing}

Genomic DNA was extracted from fresh material using the Nucleo Spin Plant II Kit (Machery-Nagel; Düren, Germany). Various regions of the ribosomal RNA (rRNA) genes including the Internal Transcribed Spacers (ITSs) were amplified using primer pairs specified previously (Gu et al., 2013) and following standard protocols (Gottschling \& Plötner, 2004; Gottschling et al., 2012).

\section{Terminology}

Terminology of cell orientation, designation of thecal plates and platelets and ornamentation follows Hoppenrath et al. (2013), but cell width is corrected towards cell depth (i.e. dorsoventral width). In the present study, terminology for measurements in the periflagellar area is defined for future unambiguous descriptions (Supplementary fig. S2). The term 'wing' 
was often used in the older literature as part of the spine in planktonic species of Prorocentrum. In the new definitions proposed by Hoppenrath et al. (2013), 'wing' is used (in a strict sense) for a thecal projection of a periflagellar platelet being broader than high, and the spine of platelet 1 is here described as having a 'sail'. The term 'mucron' (i.e. small tooth; Cohen-Fernandez et al., 2006) is used for a small posterior structure or extension of one of the lateral thecal plates of Prorocentrum.

\section{Results}

\section{General morphology}

Using light microscopy (LM), all 12 clonal strains were identical in terms of morphology. Strain A10 was selected for the epitype and will be described and depicted in detail (Figs $1-50 ; 53,55,56,58$ ). Cell size for all strains ranged from 40.4 to $58.2 \mu \mathrm{m}$ in length and 24.4 to $35.9 \mu \mathrm{m}$ in depth (Table 1), with strains grown at a salinity of 33 being slightly larger compared with strains grown at a salinity of 15. Mean size for strain A10 was $48.8 \mu \mathrm{m}$ in length and $29.6 \mu \mathrm{m}$ in depth. Motile cells had both a longitudinal and a wavy transverse flagellum arising from the apical periflagellar area. Dividing cells kept their motility, and division was by desmoschisis along the sagittal suture (i.e. the two large thecal plates were shared between the two daughter cells: Figs 13, 14).

Cells were strongly compressed laterally (Fig. 6) and in lateral view, they were asymmetrically obovate in outline and had a rounded or slightly truncated and/or indented anterior part and an acute posterior end (Figs 1-14). Both dorsal and ventral sides of the theca were convex with the broadest part of the cells in the upper half of the cell. The dorsal convexity was stronger, and the ventral side could appear nearly a plane (Fig. 11). The posterior angle was variable, ranging from $68.8^{\circ}$ to $109.8^{\circ}$ (Table 2). At the apex, cells terminated with a distinct apical spine of $6.4 \pm$ $0.5 \mu \mathrm{m}$ in length (Table 2). Light microscopy also revealed a conspicuous line of rod-shaped trichocysts with a length of $\sim 7 \mu \mathrm{m}$ visible in the apical area (Fig. 2) and a poroid surface of the theca (Fig. 3). Under a coverslip, living cells were regularly observed with extruded trichocysts radiating from the cell surface, especially in the posterior part (Fig. 5).

A large $U$ - to $\mathrm{V}$-shaped nucleus with thick, dinokaryotic chromosomes (Fig. 4) extended about $65 \%$ of the cell length (Fig. 9). Two lobed and retiform, brownish chloroplasts were parietally arranged (Figs 5, 10). No stalked pyrenoid with starch sheath was visible in LM. However, a densely stained area was observed in the centre of Lugol-fixed cells (Figs 11, 12), in which the chloroplast seemed to lack perforations (Fig. 10). A large, round or bilobatedly kidney-shaped, hyaline area (presumably a pusule) was occasionally visible in the anterior part of the cell (Figs 6,7).

Scanning electron microscopy confirmed the general appearance of the cell (Figs 15-31) and revealed the three-dimensional shape of both thecal plates in more detail (Figs 17-22). Moreover, a number of structural details could be demonstrated. The spine consisted of a broad spearhead-shaped part arranged perpendicular to the sagittal plane and it was slightly variable among individual cells (it also varied depending on the individual perspective in the microscope). On the left lateral side, the spine extended to the ventral side as a steeply narrowing sail oriented in the cell's sagittal plane (Figs 23-28). The total length of the spine (in SEM specimens) was $6.2 \pm 0.6 \mu \mathrm{m}(\mathrm{n}=11)$. Opposite the large spine, there was a small wing (Figs 23, 38).

At the posterior end of the cell, there was a small triangular extension of the theca (i.e. mucron) bent slightly upwards. However, the mucron was only present on the left thecal plate (Figs 29-31). Between the two thecal plates there was an intercalary band of varying width, which was densely striated transversally (0.4-0.7 $\mu \mathrm{m}$ between stripes, $\mathrm{n}=15$; Figs 17-20, 31, Supplementary fig. S7) and occasionally a few horizontal lines were also observed (Fig. 31, Supplementary fig. S7). In a few specimens the transition between intercalary band and theca was marked by a dense row of small, roundish depressions (Fig. 19).

The surface of both thecal plates was foveate with round or oval (or occasionally more kidney shaped and elongated) depressions with a density of $1.24 \pm 0.20 \mu \mathrm{m}^{-2}$

Table 2. Morphometric measurements for Prorocentrum micans strain A10 as measured with light microscopy (LM) or scanning electron microscopy (SEM).

\begin{tabular}{lccc}
\hline Trait & Mean \pm SD & Min - Max & $N$ \\
\hline Length LM $(\mu \mathrm{m})$ & $48.8 \pm 1.6$ & $40.5-51.9$ & 87 \\
Depth LM $(\mu \mathrm{m})$ & $29.6 \pm 1.4$ & $24.4-32.4$ & 87 \\
L/D LM ratio & $1.65 \pm 0.06$ & $1.50-1.78$ & 87 \\
Posterior angle LM $\left(^{\circ}\right)$ & $82.1 \pm 6.0$ & $68.8-109.8$ & 87 \\
Spine length LM $(\mu \mathrm{m})$ & $6.4 \pm 0.46$ & $5.1-7.3$ & 50 \\
Large pore diameter SEM $(\mu \mathrm{m})$ & $0.66 \pm 0.05$ & $0.55-0.76$ & 31 \\
Small pore diameter SEM $(\mu \mathrm{m})$ & $0.18 \pm 0.01$ & $0.16-0.22$ & 33 \\
Mini pore diameter SEM $(\mu \mathrm{m})$ & $0.12 \pm 0.01$ & $0.11-0.13$ & 20 \\
Depression density SEM $\left(\mu \mathrm{m}^{-2}\right)$ & $1.24 \pm 0.20$ & $0.96-1.74$ & 20 \\
Depression area SEM $\left(\mu \mathrm{m}^{2}\right)$ & $0.18 \pm 0.08$ & $0.02-0.49$ & 500 \\
Number large pores right plate SEM & $76.0 \pm 6.8$ & $63-87$ & 14 \\
Number small pores right plate SEM & $50.4 \pm 5.1$ & $42-63$ & 13 \\
Number large pores left plate SEM & $78.0 \pm 6.6$ & $65-89$ & 19 \\
Number small pores left plate SEM & $53.9 \pm 8.3$ & $39-75$ & 19 \\
Depth periflagellar area SEM $(\mu \mathrm{m})$ & $6.3 \pm 0.5$ & $5.0-7.6$ & 25 \\
Length periflagellar area SEM $(\mu \mathrm{m})$ & $3.4 \pm 0.4$ & $2.9-4.5$ & 17 \\
Width ap SEM $(\mu \mathrm{m})$ & $0.7 \pm 0.1$ & $0.6-0.9$ & 7 \\
Length ap SEM $(\mu \mathrm{m})$ & $1.3 \pm 0.1$ & $1.1-1.5$ & 7 \\
Width fp SEM $(\mu \mathrm{m})$ & $0.9 \pm 0.1$ & $0.8-1.1$ & 14 \\
Length fp SEM $(\mu \mathrm{m})$ & $1.7 \pm 0.1$ & $1.4-1.9$ & 11 \\
\hline Abbrevatons $\mathrm{L} / \mathrm{D}$ ) & &
\end{tabular}

Abbreviations: L/D: length/depth; ap: accessory pore; fp: flagellar pore. 

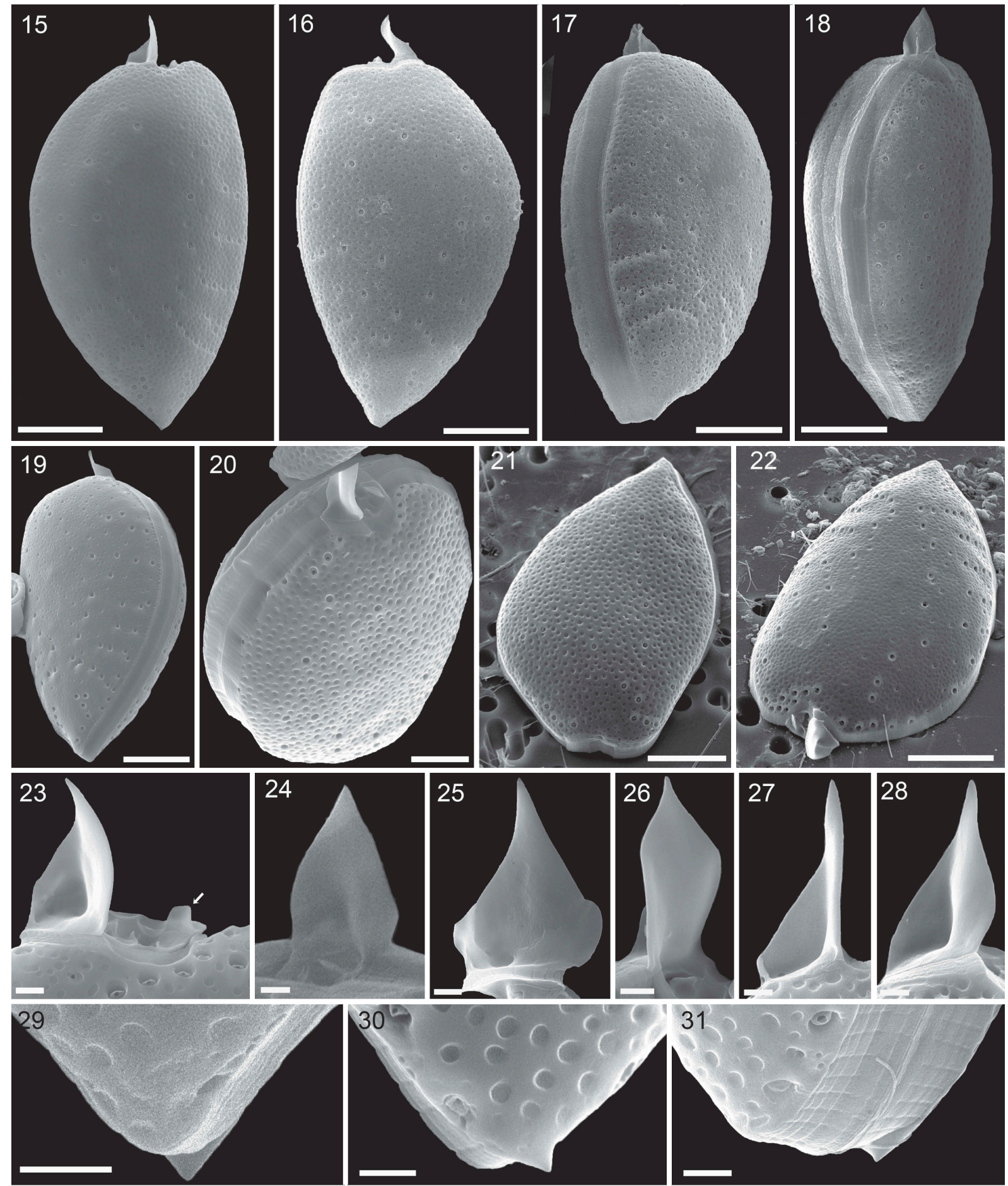

Figs 15-31. Prorocentrum micans (strain A10, SEM). Figs 15-20. Entire cells in right thecal view (Fig. 15), left thecal view (Fig. 16), ventral-lateral view (Fig. 17), dorsal-lateral view (Fig. 18), left thecal view (Fig. 19) and apical view (Fig. 20). Figs 21, 22. Left thecal plate (Fig. 21) and right thecal plate (Fig. 22) in apical view to illustrate three-dimensional shape of the thecal plates. Figs 23-28. Different views of the apical spine. Note the short wing (arrow in Fig. 23) opposite to the spine. Figs 29-31. Different views of the short, triangular posterior termination (mucron) on the left thecal plate. Scale bars $=10$ $\mu \mathrm{m}$ (Figs 15-19, 21, 22), $5 \mu \mathrm{m}$ (Fig. 20), $1 \mu \mathrm{m}$ (Figs 23-31).

$(\mathrm{n}=20)$. The area of the depressions ranged from 0.02 to $0.49 \mu^{2}$ (Table 2). Presence and development of depressions seemed to depend on thecal age. Presumably, recently formed thecal plates were free of depressions (Figs 37, 40), and various developmental stages in size and depth of the depressions were observed (Fig. 19). Moreover, dorsal or ventral views (i.e. non-lateral views) revealed cells with markedly differing foveate ornamentation of both thecal plates (Fig. 38, Supplementary figs S4-S6). 


\section{Thecal pores}

There were three different types of thecal pore present. Firstly and most obviously, there were large trichocyst pores consisting of a large canal with an outer diameter of $0.66 \pm 0.05 \mu \mathrm{m}(\mathrm{n}=31)$. In the centre of the canal, a protuberance was visible with an inner opening either being very small (Figs 42, 43, Supplementary figs S8, S9) or wide (Fig. 44, Supplementary figs S10, S11), the latter probably representing the stage after trichocyst extrusion. From internal thecal views, the tubular structure of large trichocyst pores was discernible (Figs $35,36,45,46$ ); they extended for $\sim 0.6 \mu \mathrm{m}$ inside of the theca with an inner opening (although mainly covered by fibrous material in SEM preparations) of $\sim 0.3 \mu \mathrm{m}$ diameter (Fig. 48). Secondly, there were small pores present (Figs 40,42) which predominantly were recessed and located in the centre of a round depression (Fig. 42). The opening of these small pores had a diameter of $0.18 \pm 0.01 \mu \mathrm{m}(\mathrm{n}=33)$. Internal theca view revealed that the small pores were also tubular but with a distinctly smaller inner extension $(\sim 0.07$ $\mu \mathrm{m})$ and inner diameter $(\sim 0.2 \mu \mathrm{m})$ (Figs. $45,46,49)$. Finally, there was a third type of pore present, which was not located inside a depression and whose diameter was the smallest ( 0.11 to $0.13 \mu \mathrm{m}, \mathrm{n}=20$ ). These mini-pores were present on both thecal plates, were consistently restricted to the most posterior part of the cells, and they often formed small clusters (Fig. 47).

Large and small pores were abundant on both thecal plates (Table 2) with $\sim 77$ and 52 large and small pores per plate, respectively, leaving only an elongated, narrow central area free of pores. Large trichocyst pores were densest in the lower third of the thecal plates, where they were mainly arranged in radial rows around the margins (Figs 32-37, 51, 52). The two most posteriorly located rows of large pores were arranged in a semicircle. Upwards, there were
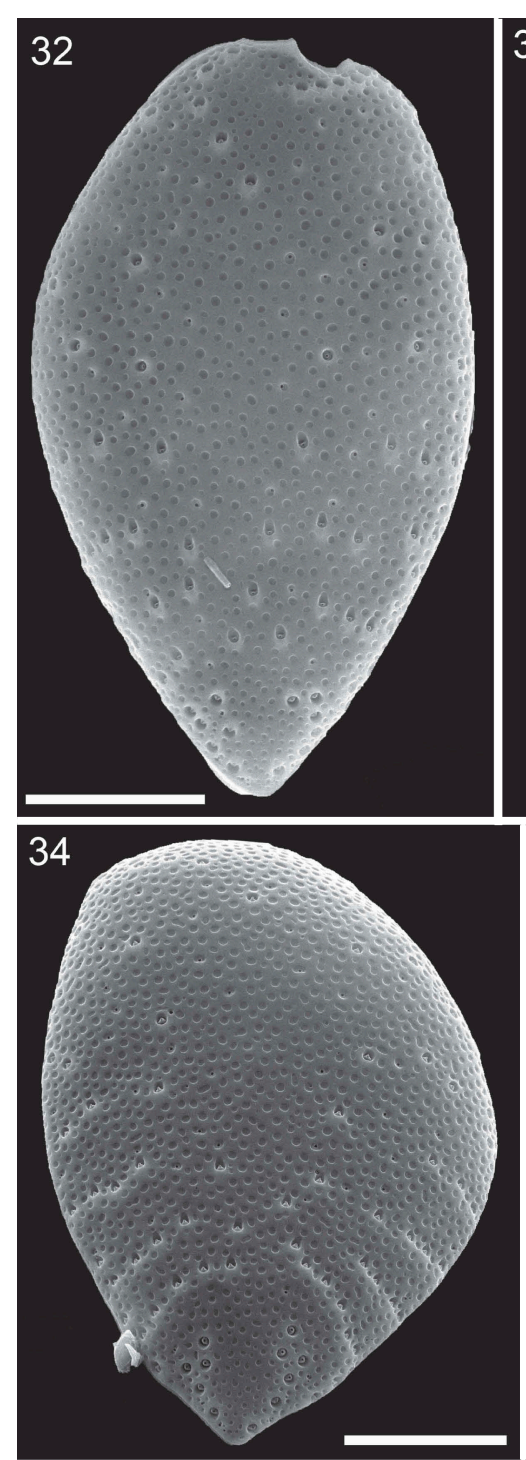
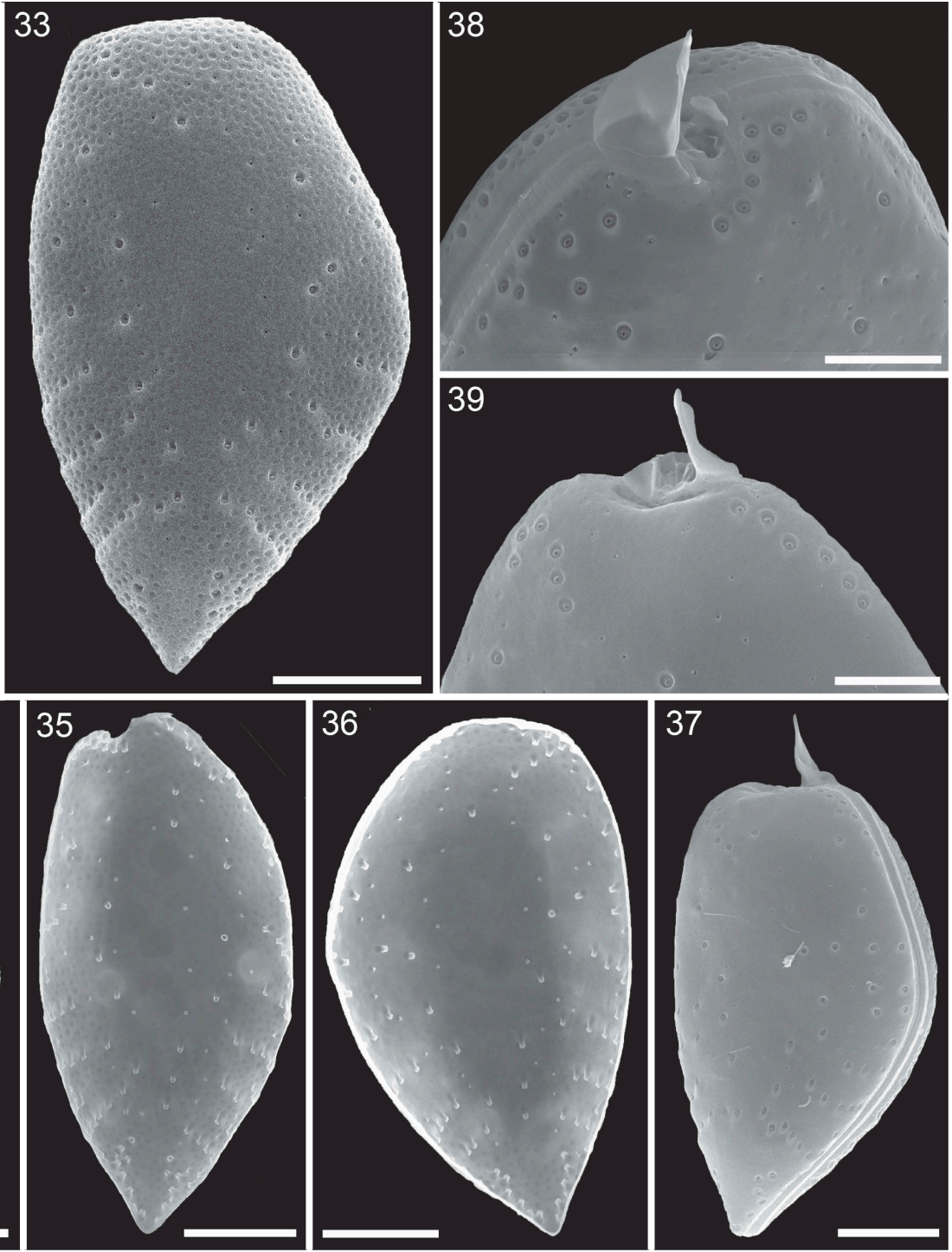

Figs 32-39. Surface structure and pore patterns of Prorocentrum micans (strain A10, SEM). Fig. 32. Right thecal plate. Fig. 33. Left thecal plate. Fig. 34. Left thecal plate in posterior view. Fig. 35. Right thecal plate in internal view. Fig. 36. Left thecal plate in internal view. Fig. 37. Entire cell with a presumably newly formed left thecal plate free of surface depressions. Figs 38, 39. Apical pore pattern of the right (Fig. 38) and left (Fig. 39) thecal plate. Scale bars $=10 \mu \mathrm{m}$ (Figs 32-37) or $5 \mu \mathrm{m}$ (Figs 38, 39). 


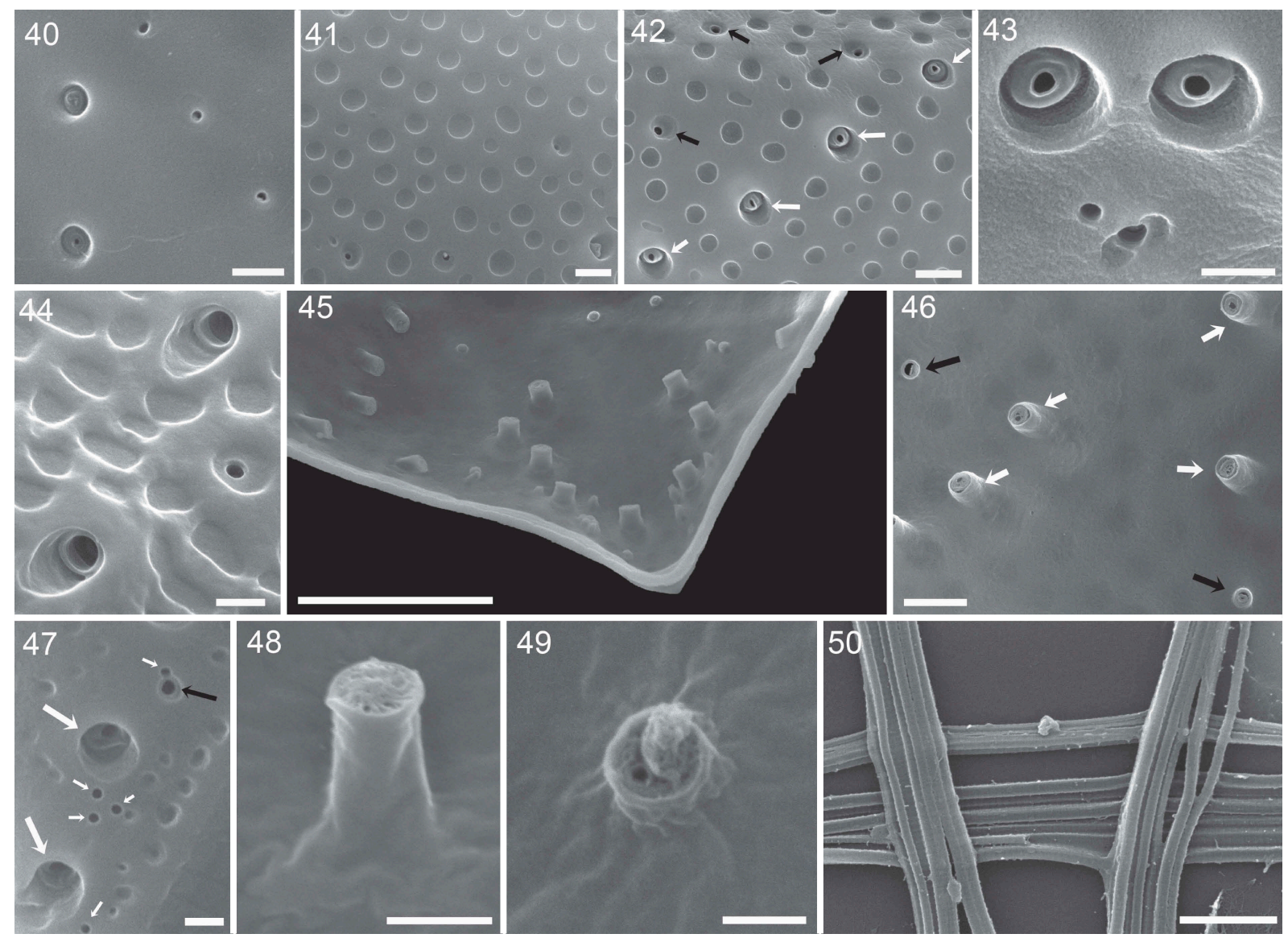

Figs 40-50. Surface structure and pores of Prorocentrum micans (strain A10, SEM). Fig. 40. Smooth surface of a presumably newly formed thecal plate with large trichocyst pores on the left and small pores on the right side. Fig. 41. Detailed view of size and shape of the surface depressions (foveate ornamentation). Fig. 42. Large trichocyst pores (white arrows) and small pores (black arrows). Fig. 43. Detailed view of the fine structure of large trichocyst pores. Fig. 44. Two large trichocyst pores with a sloped opening. Fig. 45. Internal view of the posterior part of the left thecal plate showing tubular structure of thecal pores. Fig. 46. Detailed internal view with large trichocyst pores (white arrows) and small pores (black arrows). Fig. 47. Enlarged view of the posterior part of the thecal plate showing large trichoycst pores (large white arrows), a small pore (black arrow) and a few mini-pores (small white arrows). Figs 48, 49. Detailed internal view of a large trichocyst pore (Fig. 48) and a small pore (Fig. 49). Fig. 50. Bundles of extruded trichocysts showing the tetragonal and densely striated structure. Scale bars $=5 \mu \mathrm{m}$ (45), $1 \mu \mathrm{m}$ (Figs 40-42, 46, 50), $0.5 \mu \mathrm{m}$ (Figs 43, 44, 47, 48), $0.2 \mu \mathrm{m}$ (Fig. 49).

usually four rows of large pores on each side consisting of usually three to six pores per row. Occasionally, these rows were located in slightly recessed depressions leading to a somewhat serrated appearance of the theca (Figs 33, 34). In the lower half, but not for the most posterior part of the cell, the deep cavities of trichocyst pores usually had a flat angle slope pointing towards the anterior or lateral side of the cell (Figs 32, 34-37, 44).

In the apical area, large trichocyst pores formed some characteristic patterns. On the right theca, there was a winding row of usually eight pores $(7-10, \mathrm{n}=$ 30) starting just below the apical spine and following the anterior excavation to the ventral side of the cell (Fig. 38). On the dorsal side of the left plate, there was a row of usually six pores $(5-7, n=24)$ along the plate margin and starting dorsally from the spine. The area below the periflagellar area of the left plate was free of pores. The apical pore pattern of the dorsal right theca and of the ventral left theca were more variable and basically consisted of a few pores along the margin and a few pores in an arched inwards running row (Figs 38, 39). In SEM preparation, extruded trichocysts were abundant. They were tetragonal, about $0.11 \mu \mathrm{m}$ in width and had a very fine horizontal striation (Fig. 50).

\section{Periflagellar area}

The cell apex was formed by the periflagellar area, which was about $6 \mu \mathrm{m}$ deep and $3 \mu \mathrm{m}$ wide (Table 2). It fitted into place between both thecal plates in a gap with a long and drawn out bend of the left plate and an additional, broadly $\mathrm{V}$-shaped, indentation of the right plate (Fig. 53). The periflagellar area was composed of nine platelets surrounding a flagellar pore ( $\mathrm{fp}$ ) and an accessory pore (ap) (Figs 54-61). One of the regular platelets (i.e. platelet 6) was consistently split into two parts (platelet formula: $123456 \mathrm{a}, \mathrm{b} 7$ 8). The fp was 


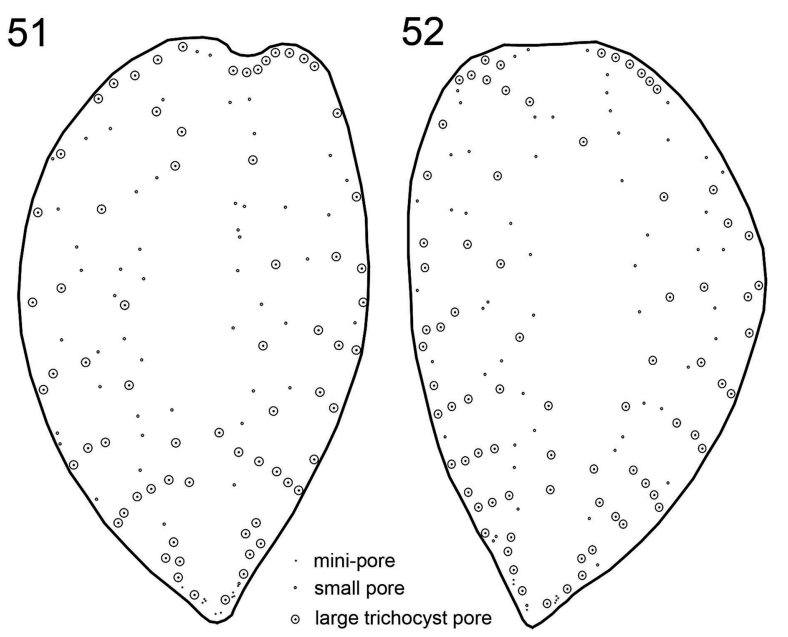

Figs 51, 52. Schematic drawing of a representative pore pattern of the right (Fig. 51) and left (Fig. 52) theca of Prorocentrum micans (strain A10).

irregular in shape, generally longer than wide in right lateral to apical view $(\sim 1.7 \mu \mathrm{m}$ long, $0.9 \mu \mathrm{m}$ wide, Table 2; for orientation see Supplementary fig. S1B) and surrounded by platelets $3,5,6 \mathrm{~b}$ and 8 . The ap was similar in shape but smaller $(\sim 1.3 \mu \mathrm{m}$ long, $0.7 \mu \mathrm{m}$ wide, Table 2 ) and surrounded by platelets 7 and 8 . Both pores internally had additional lip-like structures (Figs 58, 59), forming a tubular and funnel-like extension into the cell (Fig. 55), which was also visible in LM with UV excitation (Fig. 9).

The triangular platelet 1 was the largest and carried the long spine with sail, whereas the triangular but distinctly smaller platelet 4 on the opposite edge of the periflagellar area supported a short (height: $0.8 \pm 0.1 \mu \mathrm{m}$; range $0.6-1.1 \mu \mathrm{m} ; \mathrm{n}=15$ ) wing (Figs 23, 38, 54, 56-58) running along almost all of the suture between platelet 4 and platelets 3 and 5 (width: $1.5 \pm 0.3 \mu \mathrm{m}$, range 1.1-2.0 $\mu \mathrm{m} ; \mathrm{n}=$ 20). On the other platelets, very short, irregular platelet lists were present occasionally (Fig. 60). The number and arrangement of apical platelets of strain A10 were confirmed by SEM for two of the other Kiel Bight strains (i.e. B11, D11). Size and shape of single periflagellar platelets within the clonal materials were slightly variable (Supplementary figs S12-S24). For two cells, a variation in platelet configuration was observed, in which platelet 6 a anomalously was in contact with platelet 1 (Supplementary figs S25, S26).

\section{Molecular diagnostics}

rRNA sequences of strains A10, B11 and D10 (Table 1) were deposited in GenBank as entries MK405477, MK405478, MK405479 and MK405480. The sequence of the strain A10 (i.e. from which the epitype was prepared) compared with other sequences assigned to
P. micans and to closely related species of Prorocentrum is shown in Fig. 62. Although not entirely identical, sequences associated with $P$. micans showed four autapomorphic (i.e. diagnostic) positions, delimiting it from all other species of Prorocentrum (including $P$. koreanum).

\section{Toxins}

All strains were negative for the presence of okadaic acid. Due to slightly different biomass available for different strains, the limit of detection varied between 3.1 and $5.2 \mathrm{fg} \mathrm{cell}^{-1}$.

\section{Discussion}

Reliable determination of species is a necessary prerequisite for any applied research in ecology, biogeography and experimental biology. This is particularly true for taxonomically challenging groups such as protists, including Prorocentrum which is the focus of the present study. The original material of the type species, $P$. micans, in the Ehrenberg collection (BHUPM) provides information about the cell shape being obovoid, rounded anteriorly, acute posteriorly, more flattened ventrally and convex dorsally (Kusber et al., 2005). The cells in Ehrenberg's drawings are somewhat more symmetrical than the physical cells available in micas. Preserved cells are 45.0-46.8 $\mu \mathrm{m}$ long (without spine) and 28.2-30.0 $\mu \mathrm{m}$ deep $(\mathrm{n}=3)$ and a prominent, apical, 7.2-10.8 $\mu \mathrm{m}$ long $(\mathrm{n}=3)$ spine with sail is present. The foveate ornamentation, with short rows of large pores, is likewise visible in the original material, but traits such as different pore-types and their distributions over the cell surface, or the microarchitecture of the periflagellar platelets are not preserved. Today, we know that these and other morphometric details are required for an unambiguous identification of closely related species of Prorocentrum. DNA sequence information is further important for the correct determination of species in the microbial world and the application of the name $P$. micans has thus been ambiguous (ICN Art. 9.9) prior to our study.

In cases of taxonomic ambiguity, the epitypification approach (Day et al., 2010) has been successfully applied for historical scientific names in the past (Kretschmann et al., 2015, 2018; Tillmann et al., 2017). The clonal strain isolated from the type locality and documented here in much detail does not contradict the description and original material of $P$. micans (Ehrenberg, 1835; Kusber et al., 2005). The cell size, shape, thecal ornamentation and apical spine morphology cannot be distinguished from the original material, although the apical spine is slightly shorter (Table 2). However, size ranges are overlapping and we are confident that, in fact, our material is correctly determined as P. micans. Thus, epitypification of $P$. micans (see below) is possible, justified and 

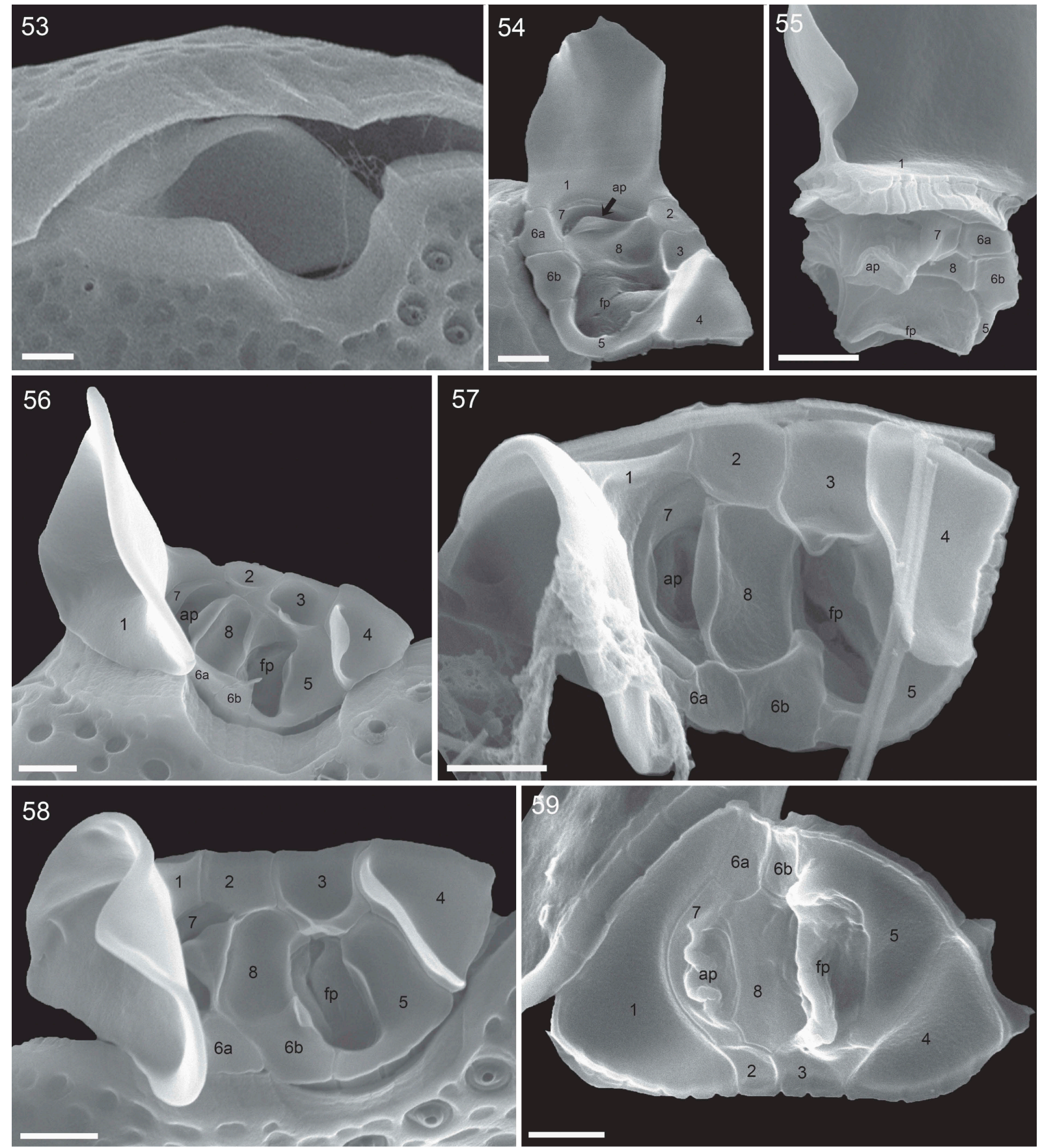

Figs 53-59. Periflagellar area of Prorocentrum micans (SEM). Fig. 53. Apical view of a cell (strain A10), whose periflagellar area was detached revealing the shape of the apical notch of both thecal plates. Fig. 54. Ventral apical view of the periflagellar area (strain D10). Fig. 55. Posterior dorsal view of a detached periflagellar area (strain A10) showing the internal extension of accessory and flagellar pore. Figs 56-58. Apical view of the periflagellar area (Figs 56, 58: strain A10; Fig. 57: strain B11). Note that in Fig. 58, a bent short list of platelet 8 is covering and hiding the accessory pore. Fig. 59. Internal view of the periflagellar area (strain B11). ap = accessory pore, $\mathrm{fp}=$ flagellar pore. Scale bars $=1 \mu \mathrm{m}$.

advised, and allows for adding morphological and molecular data to the species circumscription for unambiguous identifications in future.

In terms of morphology, information about the exact number and the arrangement of the periflagellar platelets is a striking addition made here. Such features are rarely reported for planktonic species of Prorocentrum, although they are considered crucial for a consistent taxonomy of Prorocentrales. Detailed and reliable high magnification SEM images of the apical area are difficult to obtain and, therefore, a comparison with an early drawing of the periflagellar area of P. micans (Taylor, 1980; Fensome et al., 1993) should be made with care. Twelve (instead of nine) platelets are depicted (Supplementary fig. S3), with a number of very small elements arranged around, or close to, the accessory pore (platelet formula: $12 \mathrm{a}, \mathrm{b} 3$ $456 \mathrm{a}, \mathrm{b} 7 \mathrm{a}, \mathrm{c} 8 \mathrm{a}, \mathrm{c}$ ). The relative size and shape of, 

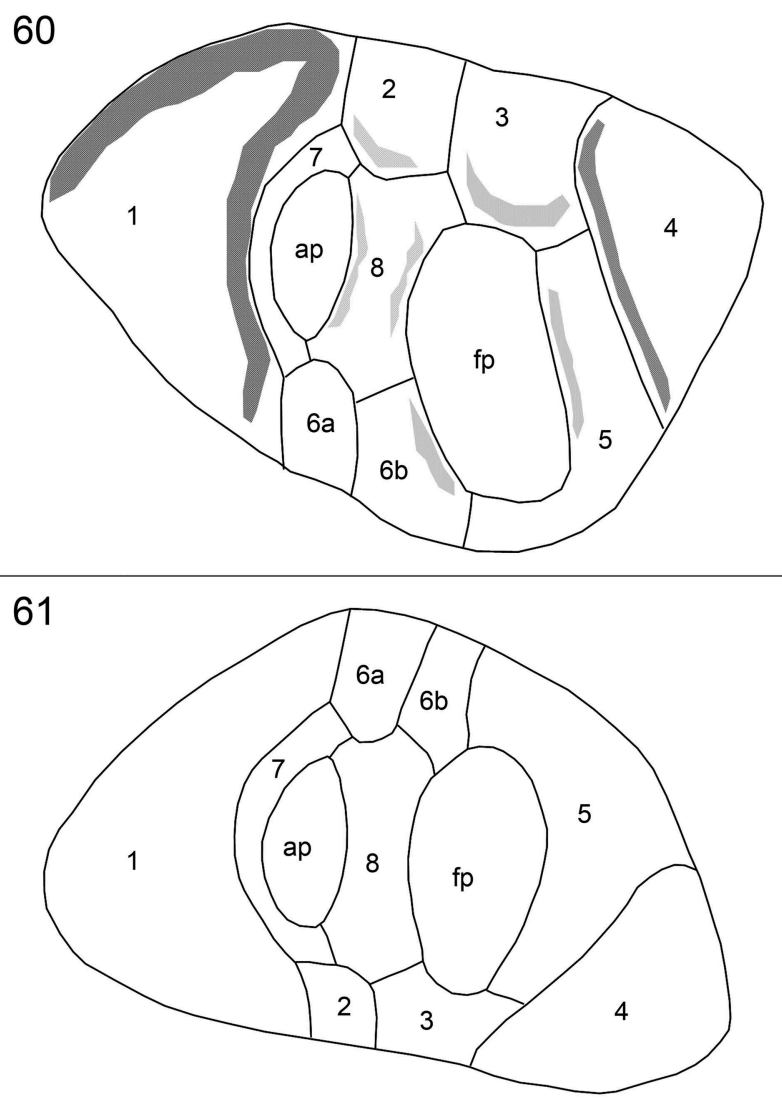

Figs 60,61 . Schematic drawings of the periflagellar area in external (Fig. 60) and internal (Fig. 61) view. ap = accessory pore, $\mathrm{fp}=$ flagellar pore.

for example, platelets 2 (with split and narrower), 3 (much deeper and larger) and 4 (much smaller) differ markedly from our observations (Figs 60, 61, Supplementary fig. S2). The periflagellar area (Taylor, 1980; Fensome et al., 1993) is inferred from stained light micrographs (provided by Hans A. von Stosch), and it remains to be clarified whether it represents a real and deviating platelet pattern (indicative of a potentially different species), or is based on preparation and/or observation artefacts. In any case, the present study indicates that the periflagellar platelet pattern is a suitable morphological trait, as stability and consistency for three clonal strains is shown. However, the number of micrographs with all plates unambiguously visible is still limited and size and shape of single platelets and, exceptionally, also the arrangement of one of the platelets (namely 6a) can vary within a clonal strain.

The presence of a mucron in the antapical thecal region is considered a diagnostic character for delimiting species or closely related species groups of Prorocentrum. In particular, the mucron of $P$. gracile (with P. sigmoides Böhm in synonymy) has been considered as a possible diagnostic character that should be evaluated based on further observations of material from different geographic regions (Cohen-Fernandez et al., 2006). We demonstrate the mucron also for $P$. micans in the present study and, thus, its presence or absence appears to be a morphological trait at the group, rather than the species, level. The mucron is a tiny structure, and further investigations of strains and field material within the $P$. micans species complex will shed light on intra- and inter-specific variability of this trait and whether peculiar character states may turn out as diagnostic for species.

We are still searching for reliable morphological traits to distinguish between (closely related) species of Prorocentrum and to the best of our knowledge, the presence of minipores are here described for the first time. They are neither recognizable on SEM images published under the name $P$. micans nor on those of related species such as $P$. gracile, $P$. koreanum or $P$. texanum (Cohen-Fernandez et al., 2006; Henrichs et al., 2013; Han et al., 2016). High magnification microscopy is needed to observe minipores, and all species of Prorocentrum are in need of a rigorous re-investigation concerning this morphological trait. The same is true for the pore pattern, but this is difficult because there is no consistent descriptive terminology available at present. As a result, text and images or drawings can be occasionally confusing, and statements such as those which say the pore patterns (around the periflagellar area and the thecal surface) of P. micans and P. koreanum are 'very different' (Han et al., 2016, p. 40) are truly open for interpretation.

We now have at hand all information necessary to identify $P$. micans reliably and unambiguously and can start to compare P. micans with previous studies, some of which are based on large morphological data sets and/or extensive DNA sequence information (Cohen-Fernandez et al., 2006, 2010; Han et al., 2016). Moreover, we are enabled now to distinguish this taxon from other similar species of Prorocentrum, in particular from the recently described P. koreanum (Han et al., 2016). The species is clearly distinct from P. micans (identified by strain A10) as inferred from rRNA sequence data, but agrees to a large extent with the LM morphology of P. micans (a phenomenon termed cryptic speciation). In turn, a Korean strain determined as $P$. micans, and with rRNA sequence data very similar to our epitype barcode (and other strains listed as P. micans), is described as morphologically different from the material investigated in the present study (Han et al., 2016), but subsequent study with high-resolution SEM images must work out such differences in detail to clarify the situation. Future research is necessary to disentangle the complex taxonomy of species similar to P. micans and with the present study a crucial step forward has been made in this respect.

\section{Epitypification}

Prorocentrum micans Ehrenberg, Abhandlungen der Königlichen Akademie der Wissenschaften in Berlin 1833, Physikalische Klasse: 307-308. 1835. 1952. Type [mica with non-fossil specimen]: Baltic Sea off 


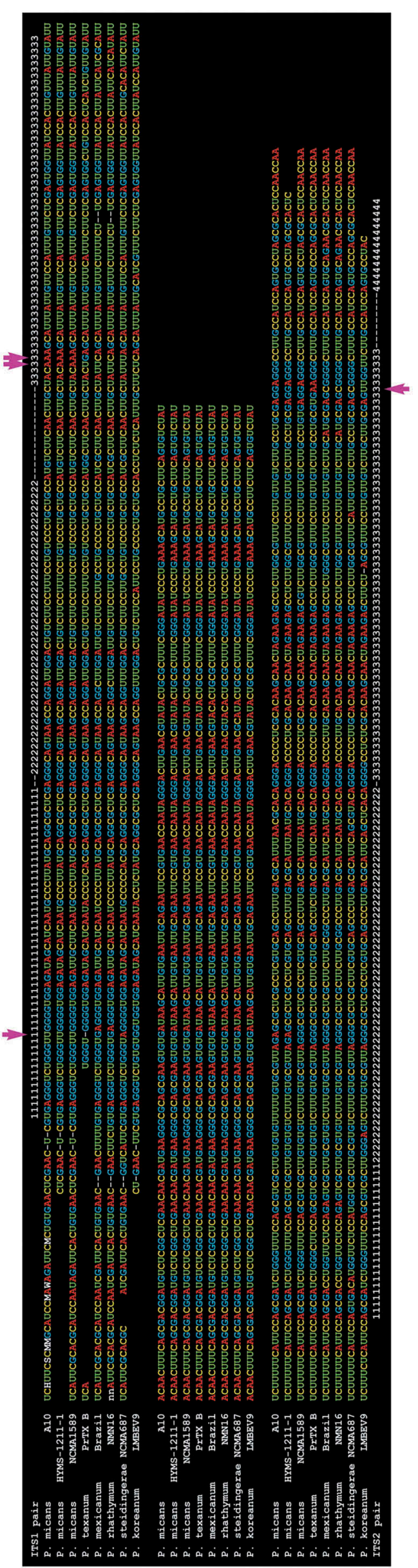
氖造

घ

की क्षै

元氙:

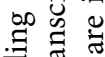

Germany. Schleswig-Holstein, Kiel, Sep 1832 [prepared Nov 25 1832]: G.A. Michaelis [Ch.G. Ehrenberg] s.n. (lectotype, designated by Kusber et al. 2005 and illustrated as figs 2-4: BHUPM 540164-1); [SEM stub]: Baltic Sea off Germany. Schleswig-Holstein, Kiel, Oct 20, 2017: K.J.S. Meier [U. Tillmann] A10 (epitype, designated here: CEDiT2018E87) [http://phycobank. org/101001].

Note: Volume 1833 of the Abhandlungen was probably printed in 1834, but was not published before 1835 due to problems with the printing costs of the copper plates (pers. comm. St. Fölske, Archiv der BerlinBrandenburgischen Akademie der Wissenschaften). The lectotypification of McLachlan et al. (1997) is to be subsumed, as the corresponding reference (Ehrenberg, 1836) was published after the protologue (Ehrenberg, 1835). Kusber et al. (2005) emphasized that the copper engravings are later interpretations of original material and are thus not eligible for typification purposes (ICN Art. 9.3).

\section{Acknowledgements}

K.J. Sebastian Meier (Kiel) collected the material at the Kiel Fjord, which is gratefully acknowledged here. David Lazarus (BHUPM, Berlin) provided access to the Ehrenberg collection and was responsible for digitizing valuable original material. We thank Stephan Wietkamp, Nancy Kühne (both Bremerhaven) and Johanna Knechtel (Munich) for DNA extraction and sequencing, and Bernd Krock and Thomas Max (both Bremerhaven) for okadaic acid toxin analysis. Financial support was provided by the PACES research programme of the Alfred Wegener Institute as part of the Helmholtz Foundation initiative in Earth and Environment.

\section{Disclosure statement}

No potential conflict of interest was reported by the authors.

\section{Funding}

This work was supported by the Alfred Wegener Institute Helmholtz Centre for Polar and Marine Research by the PACES Research Program as part of the Helmholtz Foundation initiative in Earth and Environment.

\section{Supplementary information}

The following supplementary material is accessible via the Supplementary Content tab on the article's online page at http://10.1080/09670262.2019.1579925

Supplementary figs S1-S3: Prorocentrum micans, sketch on how morphometric size measurements were performed for cell dimensions (Fig. S1) and for the periflagellar area (Fig. S2). Fig. S3. Platelet pattern of P. micans as proposed by Fensome et al. (1993).

Supplementary figs S4-S11: Surface structure and pore patterns of Prorocentrum micans strain A10 (SEM). Fig. S4. Ventral view of a cell where the right plate is smooth and the left plate is foveate. Figs S5, S6. Apical area of cells 
with one smooth and one foveate thecal plate. Fig. S7. Detailed view of a broad sagittal suture with a few vertical lines (arrows) next to the dense horizontal striation. Figs S8-S11. Examples of large trichocyst pores with the spinning-nozzle like structure visible with an inner opening either being very small (Figs S8, S9) or wide (Figs S10, S11). Scale bars $=5 \mu \mathrm{m}$ (Figs S4-S6), $1 \mu \mathrm{m}$ (Fig. S7), $0.5 \mu \mathrm{m}$ (Figs S8-S11).

Supplementary figs S12-S24: Periflagellar area of Prorocentrum micans (SEM) in apical (Figs S12-S19) or internal (Figs S20-S24) view. Figs S13-S19, S23: strain A10; Figs S12, S20, S22, S24: strain B11; Fig. S21: strain D10. Note that only plates that are visible are labelled. ap = accessory pore, $\mathrm{fp}=$ flagellar pore. Scale bar $=1 \mu \mathrm{m}$.

Supplementary figs S25, S26: Periflagellar area of Prorocentrum micans (SEM). Variation in platelet configuration: platelet $6 \mathrm{a}$ anomalously in contact with platelet 1 (arrows). Fig. S25: strain B11, Fig. S26: strain A10. Scale bar $=1 \mu \mathrm{m}$.

\section{Author contributions}

U. Tillmann: isolation, culturing, LM and SEM, drafting and editing manuscript; M. Hoppenrath: Prorocentrum terminology, drafting and editing manuscript; M. Gottschling: original concept, analysis of molecular data, taxonomy, drafting and editing manuscript.

\section{ORCID}

Urban Tillmann (D) http://orcid.org/0000-0002-8207-4382 Marc Gottschling (D) http://orcid.org/0000-0002-4381-8051

\section{References}

Abé, T.H. (1967). The armoured Dinoflagellata: I. Prorocentridae and Dinophysidae (A). Seto Sea Marine Biological Laboratory Publishers, 14: 369-389.

Bachvaroff, T.R., Gornik, S.G., Concepcion, G.T., Waller, R. F., Mendez, G.S., Lippmeier, J.C. \& Delwiche, C.F. (2014). Dinoflagellate phylogeny revisited: using ribosomal proteins to resolve deep branching dinoflagellate clades. Molecular Phylogenetics and Evolution, 70: 314-322.

Bergh, R.S. (1881). Der Organismus der Cilioflagellaten. Eine phylogenetische Studie. Morphologisches Jahrbuch, 7: 177-288, pl. 12-16.

Bhaud, Y., Soyer-Gobillard, M.O. \& Salmon, J.M. (1988). Transmission of gametic nuclei through a fertilization tube during mating in a primitive dinoflagellate, Prorocentrum micans Ehr. Journal of Cell Science, 89: 197-206.

Biecheler, B. (1952). Recherches sur les Peridiniens. Bulletin Biologique de la France et de la Belgique, Suppl. 36: 1-149.

Braarud, T. \& Rossavik, E. (1951). Observations on the marine dinoflagellate Prorocentrum micans Ehrenb. in culture. Avhandl. Norske Videnskaps-Akad. Oslo. I. Mat. Naturv Kl., 1: 3-18.

Braarud, T. \& Heimdal, B. (1970). Brown waters on the Norwegian coast in autumn 1966. Nytt Magasin for Botanik, 17: 91-97.

Brand, L.E. (1985). Low genetic variability in reproduction rates in populations of Prorocentrum micans Ehrenb. (Dinophyceae) over Georges Bank. Journal of Experimental Marine Biology and Ecology, 88: 55-65.
Bursa, A.S. (1959). The genus Prorocentrum Ehrenberg. Morphodynamics, protoplasmic structure. Canadian Journal of Botany, 37: 1-31.

Caroppo, C., Pagliari, P., Azzaro, F., Miserocchi, S. \& Azzaro, M. (2017). Late summer phytoplankton blooms in the changing polar environment of the Kongsfjorden (Svalbard, Arctic). Cryptogamie Algologie, 38: 53-72.

Cassie, V. (1981). Non-toxic blooms of Prorocentrum micans (Dinophyceae) in the Karanea Bight. New Zealand Journal of Marine and Freshwater Research, 15: 181-184.

Cohen-Fernandez, E.J., Del Castillo, E.M., Ugarte, I.H.S. \& Pedroche, F.F. (2006). Contribution of external morphology in solving a species complex: the case of Prorocentrum sigmoides (Dinoflagellata) from the Mexican Pacific Coast. Phycological Research, 54: 330-340.

Cohen-Fernandez, E.J., Pedroche, F.F., Palacios, M.R., Hernandez, S.A. \& Del Castillo, E.M. (2010). Molecular phylogeny of Prorocentrum (Dinoflagellata) from the Pacific coast of Mexico based on the parsimony analysis of fragments of LSUrDNA and SSUrDNA. International Journal of Plant Physiology and Biochemistry, 2: 29-37.

Day, J.G., Pröschold, T., Friedl, T., Lorenz, M. \& Silva, P.C. (2010). Conservation of microalgal type material: approaches needed for 21st century science. Taxon, 59: 3-6.

Dodge, J.D. (1975). The Prorocentrales (Dinophyceae). II. Revision of the taxonomy within the genus Prorocentrum. Botanical Journal of the Linnean Society, 71: 103-125.

Dodge, J.D. (1982). The Dinoflagellates of the British Isles. Her Majesty's Stationery Office, London.

Dodge, J.D. \& Bibby, B.T. (1973). The Prorocentrales (Dinophyceae) I. A comparative account of fine structure in the genera Prorocentrum and Exuviella. Botanical Journal of the Linnean Society, 67: 175-187.

Eggersdorfer, B. \& Häder, D.P. (1991). Phototaxis, gravitaxis and vertical migrations in the marine dinoflagellate Prorocentrum micans. FEMS Microbiology Letters, 85: 319-326.

Ehrenberg, C.G. (1835). Dritter Beitrag zur Erkenntnis großer Organisation in der Richtung des kleinsten Raumes. Abhandlungen der Königlichen Akademie der Wissenschaften in Berlin 1833: Physikalische Klasse, 145-336.

Ehrenberg, C.G. (1836). Über das Leuchten des Meeres. Abhandlungen der Königlichen Akademie der Wissenschaften in Berlin 1834, 411-575, tabs 411-412.

Faust, M.A., Larsen, J. \& Moestrup, O. (1999). Leaflet no 184. Potentially toxic phytoplankton 3. Genus Prorocentrum (Dinophyceae). In ICES Identification Leaflets for Plankton (Lindley, J.A., editor), 1-24. International Council for the Exploration of the Sea, Copenhagen.

Fensome, R.A., Taylor, F.J.R., Norris, G., Sarjeant, W.A.S., Wharton, D.I. \& Williams, G.L. (1993). A classification of living and fossil dinoflagellates. Micropaleontology, Special Publication, 7: 1-351.

Gómez, F., Qiu, D. \& Lin, S. (2017). The synonymy of the toxic dinoflagellates Prorocentrum mexicanum and $P$. rhathymum and the description of $P$. steidingerae sp. nov. (Prorocentrales, Dinophyceae). Journal of Eukaryotic Microbiology, 64: 668-677.

Gottschling, M. \& Plötner, J. (2004). Secondary structure models of the nuclear Internal Transcribed Spacer regions and 5.8S rRNA in Calciodinelloideae (Peridiniaceae) and other dinoflagellates. Nucleic Acids Research, 32: 307-315.

Gottschling, M., Söhner, S., Zinßmeister, C., John, U., Plötner, J., Schweikert, M., Aligizaki, K. \& Elbrächter, 
M. (2012). Delimitation of the Thoracosphaeraceae (Dinophyceae), including the calcareous dinoflagellates, based on large amounts of ribosomal RNA sequence data. Protist, 163: 15-24.

Gu, H., Kirsch, M., Zinßmeister, C., Söhner, S., Meier, K.J.S., Liu, T. \& Gottschling, M. (2013). Waking the dead: morphological and molecular characterization of extant $\dagger$ Posoniella tricarinelloides (Thoracosphaeraceae, Dinophyceae). Protist, 164: 583-597.

Han, M.S., Wang, P., Kim, J.H., Cho, S.Y., Park, B.S., Kim, J.H., Katano, T. \& Kim, B.H. (2016). Morphological and molecular phylogenetic position of Prorocentrum micans sensu stricto and description of Prorocentrum koreanum sp. nov. from southern coastal waters in Korea and Japan. Protist, 167: 32-50.

Hasle, G.R. (1950). Phototactic vertical migration in marine dinoflagellates. Oikos, 2: 162-175.

Henrichs, D.V., Scott, P., Steidinger, K., Errera, R.M., Abraham, A. \& Campbell, L. (2013). Morphology and phylogeny of Prorocentrum texanum sp. nov. (Dinophyceae): a new toxic dinoflagellate frim the Gulf of Mexico coastal waters exhibiting two distinct morphologies. Journal of Phycology, 49: 143-155.

Hernández-Becerril, D.U., Altamirano, R.C. \& Alonso, R. (2000). The dinoflagellate genus Prorocentrum along the coasts of the Mexican Pacific. Hydrobiologia, 418: 111-121.

Herrera-Sepúlveda, A., Medlin, L., Murugan, G., Sierra-Beltran, A.P., Cruz-Villacorta, A.A. \& Hernandez-Saavedra, N.Y. (2015). Are Prorocentrum hoffmanianum and Prorocentrum belizeanum (Dinophyceae, Prorocentrales), the same species? An integration of morphological and molecular data. Journal of Phycology, 51: 173-188.

Hoppenrath, M., Elbrächter, M. \& Drebes, G. (2009). Marine Phytoplankton. E. Schweizerbart'sche Verlagsbuchhandlung, Stuttgart, Germany.

Hoppenrath, M., Chomérat, N., Horiguchi, T., Schweikert, M., Nagahama, Y. \& Murray, S. (2013). Taxonomy and phylogeny of the benthic Prorocentrum species (Dinophyceae) - a proposal and review. Harmful Algae, 27: 1-28.

Jacobson, D.M. \& Anderson, D.M. (1996). Widespread phagocytosis of ciliates and other protists by mixotrophic and heterotrophic thecate dinoflagellates. Journal of Phycology, 32: 279-285.

Jeong, H.J., Yoo, Y.D., Park, J.Y., Song, J.Y., Kim, S.T., Lee, S.H., Kim, K.Y. \& Yih, W.H. (2005). Feeding by phototrophic red-tide dinoflagellates: five species newly revealed and six species previously known to be mixotrophic. Aquatic Microbial Ecology, 40: 133-150.

Jin, Q., Dong, S. \& Wang, C. (2005). Allelopathic growth inhibition of Prorocentrum micans (Dinophyta) by Ulva pertusa and Ulva linza (Chlorophyta) in laboratory cultures. European Journal of Phycology, 40: 31-37.

Kain, J.M. \& Fogg, G.E. (1960). Studies on the growth of marine phytoplankton. III. Prorocentrum micans Ehrenberg. Journal of the Marine Biological Association of the United Kingdom, 39: 33-50.

Keller, M.D., Selvin, R.C., Claus, W. \& Guillard, R.R.L. (1987). Media for the culture of oceanic ultraphytoplankton. Journal of Phycology, 23: 633-638.

Kretschmann, J., Žerdoner Čalasan, A., Kusber, W.-H. \& Gottschling, M. (2018). Still curling after all these years: Glenodinium apiculatum Ehrenb. (Peridiniales, Dinophyceae) repeatedly found at its type locality in Berlin (Germany). Systematics and Biodiversity, 16: 200-209.
Kretschmann, J., Elbrächter, M., Zinßmeister, C., Söhner, S., Kirsch, M., Kusber, W.-H. \& Gottschling, M. (2015). Taxonomic clarification of the dinophyte Peridinium acuminatum Ehrenb., $\equiv$ Scrippsiella acuminata, comb. nov. (Thoracosphaeraceae, Peridiniales). Phytotaxa, 220: 239-256.

Krock, B., Tillmann, U., John, U. \& Cembella, A.D. (2008). LC-MS/MS On Board Ship - tandem mass spectrometry in the search for phycotoxins and novel toxigenic plankton from the North Sea. Analytical and Bioanalytical Chemistry, 392: 797-803.

Kusber, W.H., Elbrächter, M. \& Jahn, R. (2005). Algae of the Ehrenberg collection -2 . The type specimens of two dinoflagellate names published by C.G. Ehrenberg. Willdenowia, 35: 205-210.

Lebour, M.V. (1925). The Dinoflagellates of the Northern Seas. The Marine Biological Association, UK, Plymouth.

Lin, S., Zhang, H. \& Jiao, N. (2006). Potential utility of mitochondrial cytochrome $b$ and its mRNA editing in resolving closely related dinoflagellates: a case study of Prorocentrum (Dinophyceae). Journal of Phycology, 42: 646-654.

Lohmann, H. (1908). Untersuchungen zur Feststellung des vollständigen Gehaltes des Meeres an Plankton. Wissenschaftliche Meeresuntersuchungender Kommission zur wissenschaftlichen Untersuchung der deutschen Meere (Kiel), 10: 129-370.

Mahoney, J.B. \& McLaughlin, J.J.A. (1977). The association of phytoflagellate blooms in lower New York bay with hypertrophication. Journal of Experimental Marine Biology and Ecology, 28: 53-65.

McLachlan, J.L., Boalch, G.T., \& Jahn, R. (1997). Reinstatement of the genus Exuviaella (Dinophyceae, Prorocentrophycidae) and an assessment of Prorocentrum lima. Phycologia, 36: 38-46.

Murray, S., Ip, C.L., Moore, R., Nagahama, Y. \& Fukuyo, Y. (2009). Are prorocentroid dinoflagellates monophyletic? A study of 25 species based on nuclear and mitochondial genes. Protist, 160: 245-264.

Nagahama, Y., Murray, S., Tomaru, A. \& Fukuyo, Y. (2011). Species boundaries in the toxic dinoflagellate Prorocentrum lima (Dinophyceae, Prorcentrales), based on morphological and phylogenetic characters. Journal of Phycology, 47: 178-189.

Okolodkov, J.B. (1998). A checklist of dinoflagellates recorded from the Russian Arctic Seas. Sarsia, 83: 267-292.

Omura, T., Iwataki, M., Borja, V.M., Takayama, H. \& Fukuyo, Y. (2012). Marine Phytoplankton of the Western Pacific. Kouseisha Kouseikaku, Tokyo.

Orr, R., Murray, S.A., Stüken, A., Rhodes, L. \& Jakobsen, K. S. (2012). When naked became armored: an eight-gene phylogeny reveals monophyletic origin of theca in dinoflagellates. PLoS ONE, 7: e50004.

Paulmier, G. (1992). Catalogue illustré des microphytes plantonique et benthique des cotes normandes. Rapports internes de la Direction des Resources Vivantes de L'IFREMER.

Paulsen, O. (1907). The Peridiniales of the Danish Waters. Meddelelser fra Kommissionen for Havundersogelser Serie: Plankton, 1: 1-26.

Pinto, J.D.S. \& Silva, E.D.S. (1956). The toxicity of Cardium edule L. and its possible relation to the dinoflagellate Prorocentrum micans. Notas e estudos di Instituto do Biologia Marítima, 12: 1-20. 
Pitcher, G.C. \& Calder, D. (2000). Harmful algal blooms of the southern Benguela Current: a review and appraisal of monitoring from 1989 to 1997. South African Journal of Marine Science, 22: 255-271.

Roberts, K.R., Heimann, K. \& Wetherbee, R. (1995). The flagellar apparatus and canal structure in Prorocentrum micans (Dinophyceae). Phycologia, 34: 313-322.

Schnepf, E. \& Winter, S. (1990). A microtubular basket in the armoured dinoflagellate Prorocentrum micans (Dinophyceae). Archiv für Protistenkunde, 138: 89-91.

Shankle, A.M., Mayali, X. \& Franks, P.J.S. (2004). Temporal patterns in population genetic diversity of Prorocentrum micans (Dinophyceae). Journal of Phycology, 40: 239247.

Shumway, S.E. (1990). A review of the effects of algal blooms on shellfish and aquaculture. Journal of the World Aquaculture Society, 21: 65-104.

Silva, E.S. (1959). Some observations on marine dinoflagellate cultures I. Prorocentrum micans Ehr. and Gyrodinium sp.
Notas e Estudos di Instituto de Biologia Marítima, Lisboa, 21: 1-15.

Stein, F. (1883). Der Organismus der Infusionsthiere nach eigenen Forschungen in systematischer Reihenfolge bearbeitet. III. Abt. II. Hälfte. Der Organismus der Arthrodelen Flagellaten. W. Engelmann, Leipzig.

Taylor, F.J.R. (1976). Dinoflagellates from the International Indian Ocean 1976 Expedition. Bibliotheca Botanica, 132: 1-234.

Taylor, F.J.R. (1980). On dinoflagellate evolution. BioSystems, 13: 65-108.

Tillmann, U., Hoppenrath, M., Gottschling, M., Kusber, W.H. \& Elbrächter, M. (2017). Plate pattern clarification of Heterocapsa triquetra sensu Stein (Heterocapsaceae, Dinophyceae). Journal of Phycology, 53: $1305-1324$.

Uchida, T. (1977). Excretion of a diatom-inhibitory substance by Prorocentrum micans Ehrenberg. Japanese Journal of Ecology, 27: 1-4. 